Proc. Indian Acad. Sci. (Farth Planet. Sci.), Vol. 90, No. 3, November 1981, pp. 217-226.

(c) Printed in India.

\title{
Archaean crustal thickness of greenstone granite belts of South India
}

\author{
C S PICHAMUTHU, R SRINIVASAN, FAREEDUDDIN and \\ APPAJI AMRIT BHASKER \\ Department of Mines and Geology, Bangalore 560001 , India
}

MS received 29 April 1981 ; revised 22 June 1981

\begin{abstract}
Archaean crustal thickness for the Dharwar craton is estimated using potash index and Rb-Sr crustal thickness grid. The volcanics of the Dharwar greenstonc belts appear to have evolved in a less than $20 \mathrm{~km}$ thick crust. Whereas the tonalitc-trondhjemite pebbles of the Dharwar conglomerates $(3250 \pm 150 \mathrm{~m} . \mathrm{y}$.) were derived from gneisses that evolved in a crust less than $20 \mathrm{~km}$ thick, the bulk of the peninsular gneisses and associated granitoids wcre emplaced in a crust 25 to $35 \mathrm{~km}$ thick. The $2000 \mathrm{~m} . \mathrm{y}$. old Closepet granite suite was cmplaced in a crust thicker than $30 \mathrm{~km}$. It is deduced that the continental crust in the region thickened from 15 to $35 \mathrm{~km}$ during a span of about $1000 \mathrm{~m} . \mathrm{y}$. between $3250 \pm 150$ to $2000 \mathrm{~m}$.y. algo. Calculations show that Archaean gecthermal gradients in Dharwar craton were three to four tines stecper when compared to the present $10.5^{\circ} \mathrm{C} / \mathrm{km}$. The thin crust and the steep geothermal gradients are reflected by the emplacement of high magnesia basalts, layered igneous complexes and the strong iron enrichment trend shown by Dharwir metavolcanics.
\end{abstract}

Keywords. Archaean; greenstone belts; crustal thickness; tectonic environments ; geothermal gradients.

\section{Introduction}

Crustal thickness has a bearing on the contemporary geothermal gradient which influences the geotectonic evolution of any terrain. Direct estimation of crustal thickness is possible for the present day crust using seismic methods. Estimation of crustal thickness during Archacan times has to be carried out by indirect methods such as (1) measuring exposed stratigraphic succession, (2) study of $P-T$ of the metamorphic mineral assemblages, and (3) by geochemical polarity indices related to crustal thickness (Condie 1973). Condie (1973) proposed potash index and Rb-Sr crustal thickness grid for estimating the crustal thickness.

In using the geochemical parameters it is necessary to ascertain that the abundance and ratios of the said alkali elements reflect the original composition and they are unaffected by later metasomatism. Critical selection of geochemical 
data is, therefore, necessary. The LMPR (Log Molecular Proportion Ratio) diagrams proposed by Beswick and Soucie (1978) provide criteria for filtering useful geochemical data. Based on such reliable geochemical data, the Archaean crustal thickness of the South Indian Shield has been estimated and the tectonic environments are interpreted in the light of the contemporary crustal thickness.

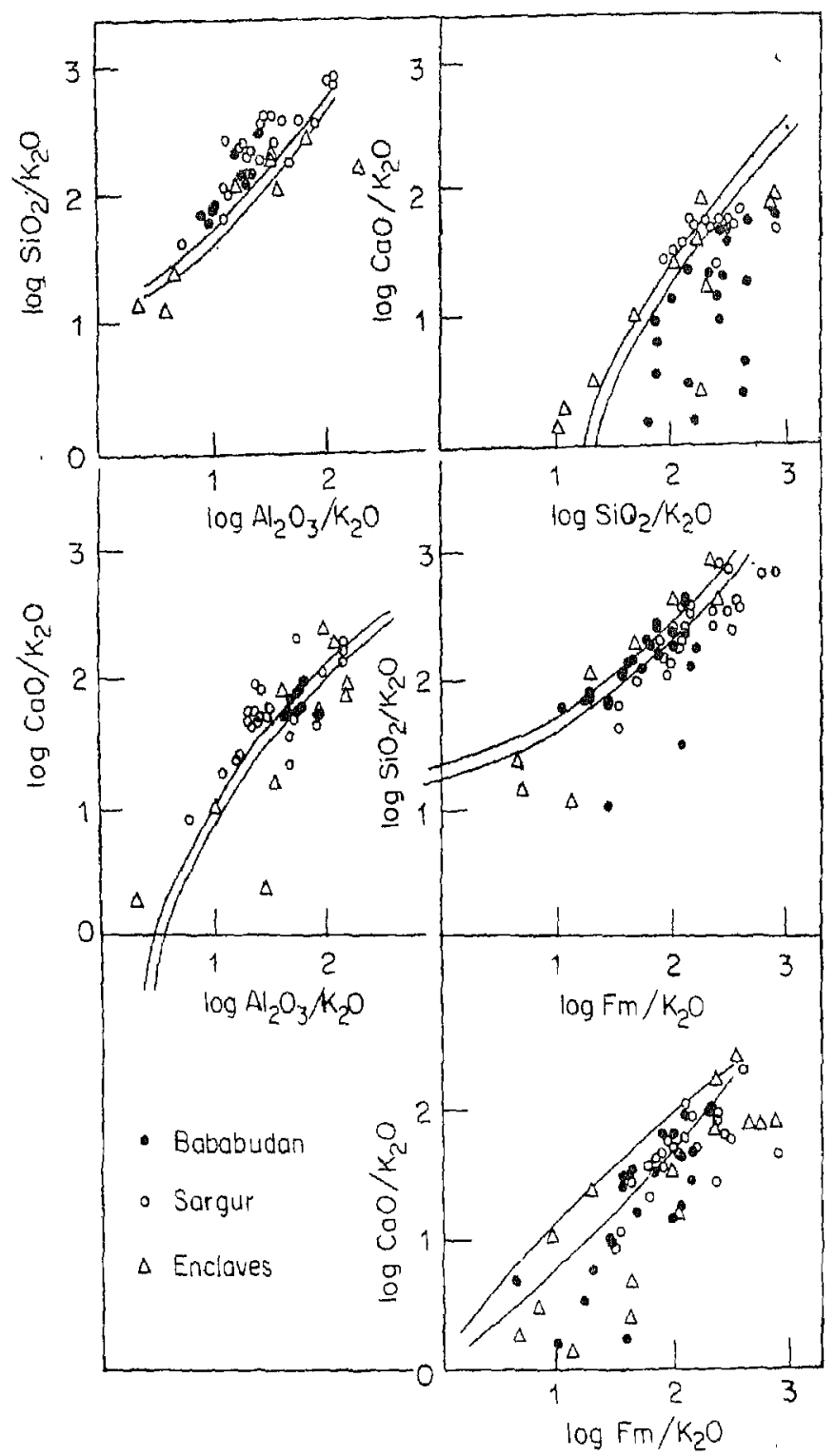

Figure 1. LMPR diagram after Beswick and Soucie (1978) showing the fiel ds occupied by unmetasomatised samples of basic igneous rocks from different tect onic regimes of the oceanic domain. The plots of mafic enclaves in gneisses, amphibolites of Sargur, and metavolcanics of Bababudan show a wide scalter outside these fields indicating that their original composition has been largely modified. 


\section{LMPR test of geochemical data}

The greenstone belts of South India are represented and well studied in Karnataka. There are over 350 chemical analyses of metabasic igneous rocks of the schist belts of Karnataka (Geochemistry Group NGRI 1977; Ananta Iyer and Narayanan Kutty 1978; Bhasker Rao and Naqvi 1978; Janardhan et al 1978; Naqvi et al 1978; unpublished data of the present authors). LMPR plots for these metabasic igneous rocks are given in figures 1 and 2, from which the following observations can:be made:

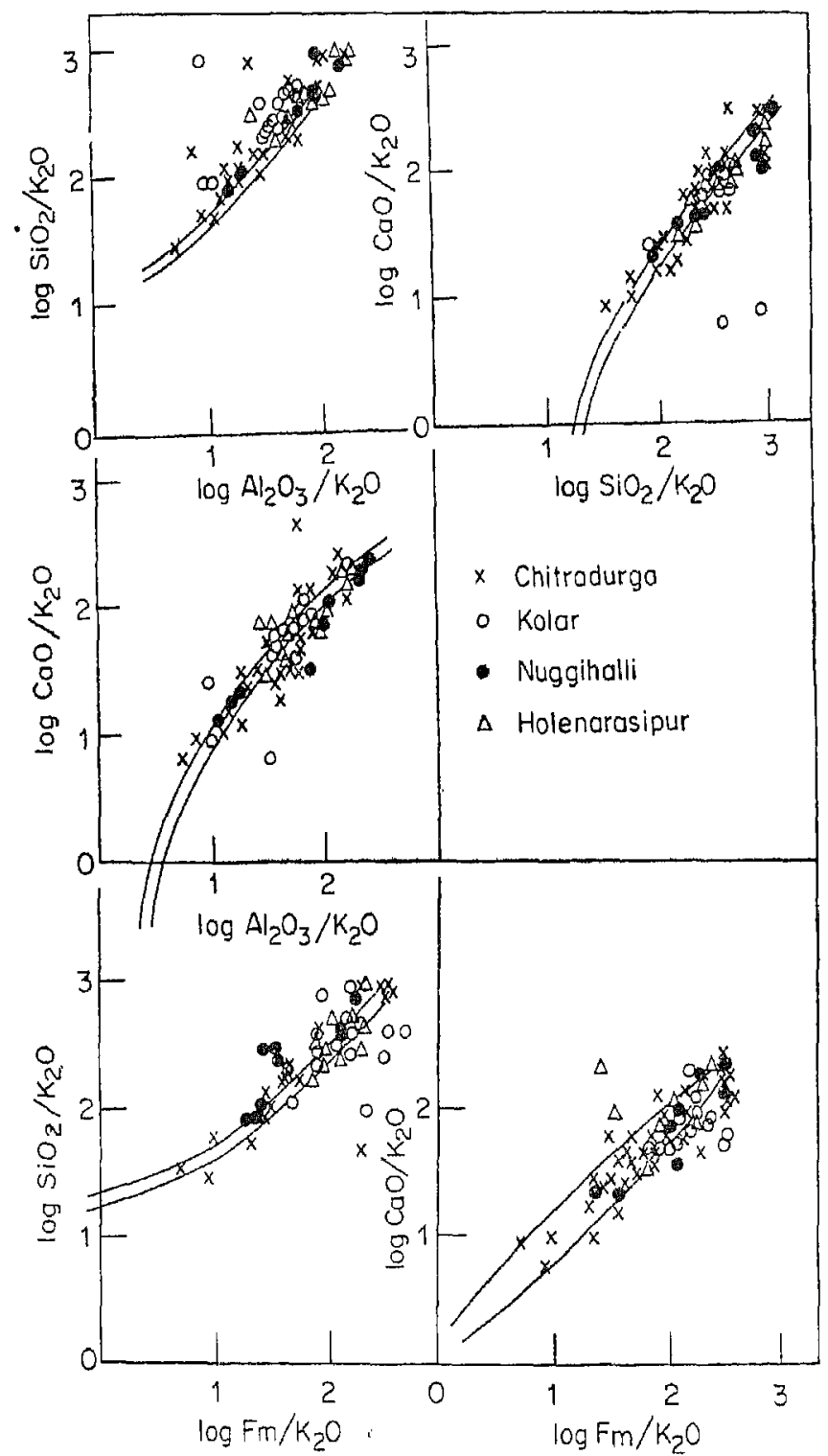

Figure 2. LMPR diagram for metamorphosed mafic rocks of Holenarasipur, Nuggihalli, Kolar, and Chitradurga greenstone belts, indicating that they have preserved their original compositions. 
(i) Amphibolite inclusions in the gneisses show a wide scatter, and therefore, their original composition has been modified.

(ii) Amphibolites of the Sargur schist complex"that have been considered as representing either root zones of the Dharwar schist belts or as rocks older than Dharwar are also modified.

(iii) The metabasalts of the Bababudan subgroup have been affected by metasomatism.

(iv) The mafic rocks of Holenarasipur and Nuggihalli schist belts have retained the original composition without much modification.

(v) The metabasalts of the Chitradurga subgroup of the Chitradurga schist belt and the amplibolites of the Kolar schist belt have retained their original chemistry.

From the above, it can be seen that the geochemical data for Nuggihalli, Holenarasipur, Kolar and Chitradurga greenstone belts are useful for geochemical modelling studies. Therefore, the data pertaining to these belts are used in the present paper for estimating the Archaean crustal thickness of the greenstone belt terrain.

The granitoids belonging to the peninsular gneiss suite constitute a mijor part of the Archaean complex of South India. Members having basement relation to the Dharwar schist belts and those showing intrusive relation into the Dharwars have been recognised. Both ortho-and para-gneisses are noticed (Divakara Rao et al 1974 ; Saha 1978; Jayaram 1980). The detailed work by Jayaram (1980) on the granitoids of Karnataka shows that the orthogneisses have a typical calc-alkaline trend.

Comparable and divergent slopes between greenstones and granitoids in the potash index diagram and also comparable crustal thicknesss values from the $K$-index and $\mathrm{Rb}$-Sr crustal thickness grid were used by Condie $(1973,1976)$ to distinguish granitoids that represent plutonic representatives of the acid volcanics of greenstone belts from those which evolved independently of greenstone belt volcanism. Such an attempt in the Dharwar craton holds the possibility for recognising the different episodes of granitoid emplacement during the course of evolution and thickening of the continental crust.

\section{Thickness of the crust of the greenstone beit terrain}

$K$-index and $\mathrm{Rb}-\mathrm{Sr}$ plots for the metavolcanics of the Dharwar greenstone belts are given in figures 3 and 4 , respectively. The crustal thickness $C$ is given in table 1 .

It has been proposed that the greenstone belts in Karnataka belong to an older and younger suite (Srinivasan and Sreenivas 1972; Naqvi 1976; Swaminath et al 1976; Radhakrishna and Vasudev 1977). The Holenarsipur and Nuggihalli schist belts are considered to be representative of the older greenstone belts and the Chitradurga schist belt of an younger greenstone belt. There is some difference of opinion as to whether the Kolar greenstone belt represents the older or younger greenstone belt (Radhakrishna and Vasudev 1977). 


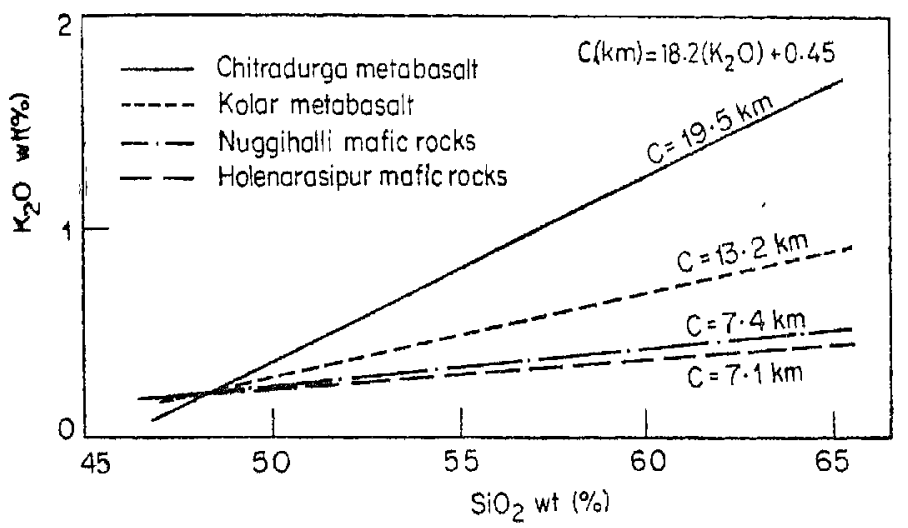

Figure 3. Crustal thickness $(C)$ estimate from $\mathrm{SiO}_{2}-\mathrm{K}_{2} \mathrm{O}$ ( $\mathrm{K}$-index) diagram after Condie (1976) for some greenstone belts of Karnataka. Each line in the diagram represents the best fit for the data of that belt. Note that greenstone belts evolved in a crust less than $20 \mathrm{~km}$ thick and the older greenstone belts (Holenarasipur and Nuggihalii) evolved in a thinner crust than younger (Kolar and Chitradurga) ones.

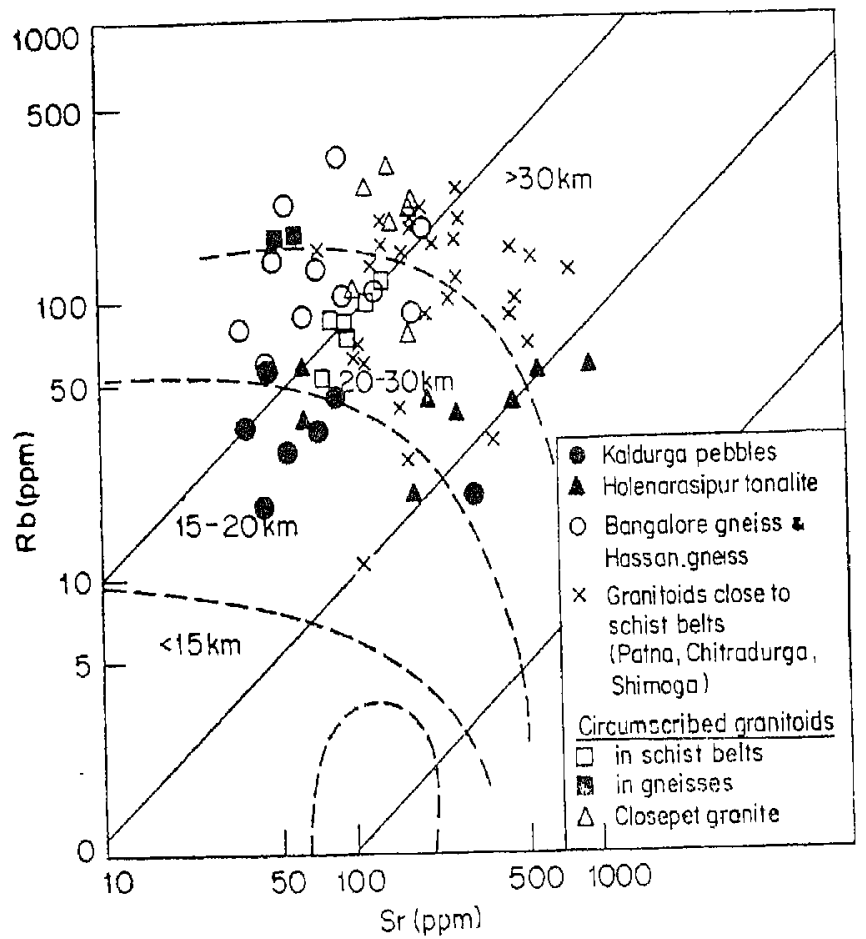

Figure 4. Plot of $\mathrm{Rb}-\mathrm{Sr}$ for the greenstone belts of Karnataka in the $\mathrm{Rb}-\mathrm{Sr}$ crustal thickness grid after Condie (1976) showing that the greenstone belts of Karnataka evolved in a crust less than $20 \mathrm{~km}$ thick. 
Table 1. Archaean crustal thickness by geochemical polarity indices for the Dharwar craton.

\begin{tabular}{lcc}
\hline & $\begin{array}{c}\text { Crustal thickness } \\
\text { based on } K \text {-index } \\
\text { in km. }\end{array}$ & $\begin{array}{c}\text { Crustal thickness } \\
\text { by Rb-Sr crustal } \\
\text { thickness grid in km; }\end{array}$ \\
\hline Greenstone belt terrain & 7.10 & 16.00 \\
Holenarsipur belt & 7.40 & $15-16$ \\
Nuggihalli belt & 13.19 & 15.00 \\
Kolar belt & 19.50 & $16-21$ \\
Chitaldurg belt & & $15-20$ \\
Gneiss-granitoid terrain & 12.10 & $18-22$ \\
Tonalite pebbles in Kaldurga conglomerate & 12.10 & - \\
Tonalites, Holenarasipur & 39.00 & $28-32$ \\
Tarikere Valley gneiss & 30.00 & $28-32$ \\
Peninsular gneiss, Hassan & 39.40 & 30 \\
Bangalore & - & $30-35$ \\
Circumscribed granitoids in schist belts & $66.00(?)$ & \\
Circumscribed granitoids in gneisses & & \\
\hline
\end{tabular}

It can be seen from the data presented in this paper based on $K$-index that the Holenarasipur and Nuggihalli schist belts evolved in a crust less than $10 \mathrm{~km}$ thick. The Kolar greenstone belt appears to have developed on a somewhat thickened crust approximately $13 \mathrm{~km}$ thick. The younger greenstone belt represented by the Chitradurga greenstone belt appears to have developed on a thicker crust $(\simeq 20 \mathrm{~km}$ ). Plots on Rb-Sr grid indicate that the greenstone belts evolved on a thinner crust, less than $20 \mathrm{~km}$ thick.

\section{Archaean crustal thickness for the gneissic terrain}

$K$-index and $\mathrm{Rb}$-Sr plots for the granitoids of Karnataka are given in figures 5 and 6 , and the thickness values are given in table 1. It is seen that the $3250 \pm 150 \mathrm{~m} . \mathrm{y}$. old tonalite pebbles of the Kaldurga conglomerate (Venkatasubramanian and Narayanaswamy 1974)? and the $3358 \pm 66 \mathrm{~m} . \mathrm{y}$. tonalites and trondhjemites of the Holenarasipur region (Beckinsale et al 1980 ) have $K$-index values characteristic of granitoids emplaced in a crust less than $15 \mathrm{~km}$ thick. The $\mathrm{Rb}$-Sr ratio for these indicates that they were emplaced in a crust $15-20 \mathrm{~km}$; thick; this corresponds to the thickness indicated by the volcanics of the younger greenstone belts, such as those of Kolar and Chitradurga.

A comparison of the slopes for the tonalite pebbles of Kaldurga and the Tarikere valley gneisses in the $K$-index diagram shows that the valley gneisses evolved in a much thicker crust, greater than $30 \mathrm{~km}$ thick. This implies that the Tarikere valley gueisses did not constitute the provenance rocks for the pebbles in the Kaldurga conglomerate. A majority of the peninsular gneiss compositions indicate a crustal thickness of 20 to $30 \mathrm{~km}$. Circumscribed gneissic granitoids occurring within the greenstone belts and those that border the greenstone belts were emplaced in a crust about $28-32 \mathrm{~km}$ thick. Circumscribed gneissic granites in the gneissic 


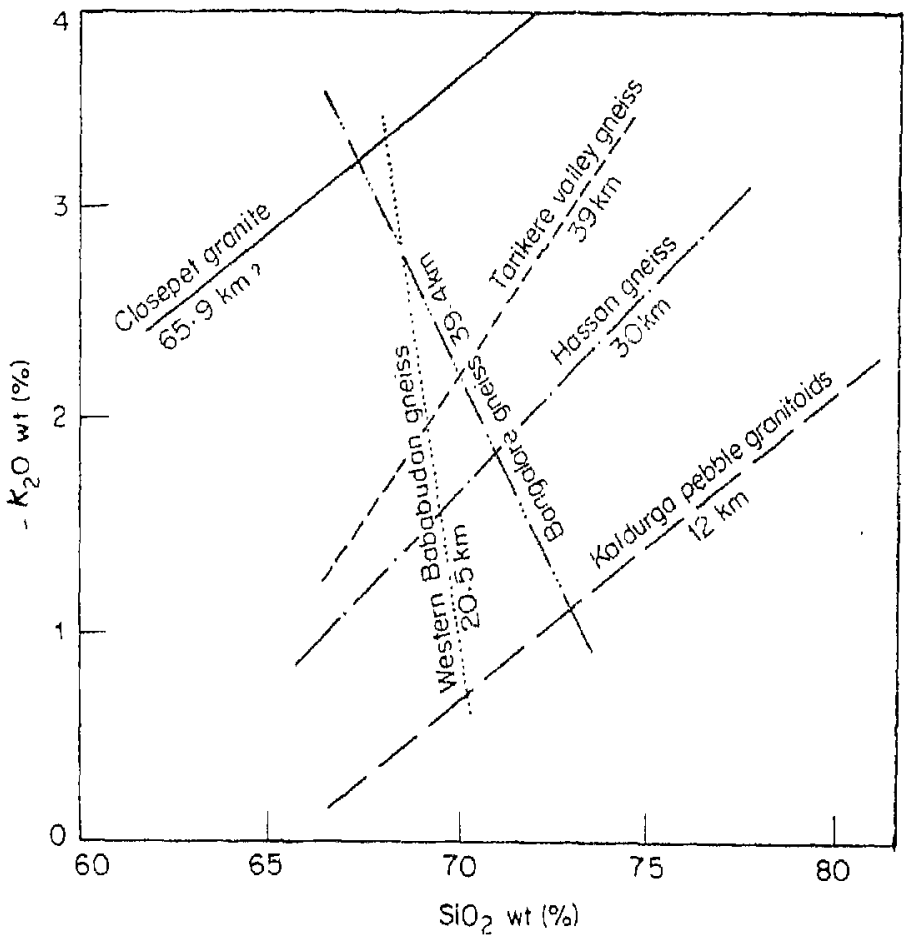

Figure 5. $K$-index plots for crustal thickness estimation of gneissic terrain. The older tonalites represented by pebbles evolved in a thinner crust, while majority of the members of the peninsular gneisses evolved when the crust had, been thickened to more than $25 \mathrm{~km}$. Closepet granite was emplaced in a much more thickened crust.

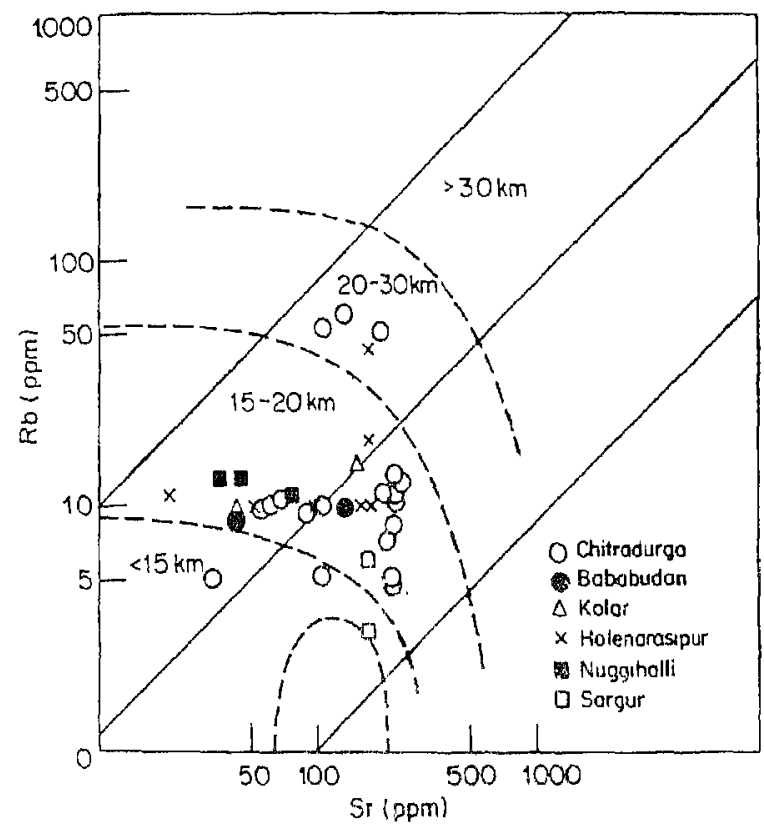

Figure 6. Rb-Sr plot for the peninsular gneisses and the Closepet 'granite of Karnataka. Note that majority of the gneisses were emplaced when the crust was more than $25 \mathrm{~km}$ thickness, whereas the older tonalites evolved in a crust less than $20 \mathrm{~km}$ thick, a thickness corresponding to that of the crust at the time of evolution of younger greenstone belts. 
terrain, such as Arasikere granite, were emplaced in a crust about $30 \mathrm{~km}$ thick. The Closepet granite suite was emplaced in a crust about 30 to $35 \mathrm{~km}$ thick.

The observed patterns indicate that prior to the development of the younger greenstone belts, the crust was thinner than $20 \mathrm{~km}$, and that much of the granitic matter was emplaced subsequent to the greenstone belt evolution. It is interesting to note from the $K$-index plots of gneisses and greenstones that some of the granitoids such as tonalites in the Holenarasipur belt and the pebble gneisses, have a slope comparable to that of the greenstone belt volcanics. These probably represent the plutonic equivalents of greenstone belt volcanism. However, the majority of the granitoids constituting the peninsular gneiss have slopes different from the greenstone belt volcanics. This suggests that most of the granitoids are unrelated to the greenstone belt volcanism.

It can thus be deduced that :

(i) The older greenstone belts were emplaced in a crust 10-12 km thick.

(ii) A first phase of tonalite emplacement was probably responsible for the thickening of the crust to $15-17 \mathrm{~km}$.

(iii) The younger greenstone belts'developed on a 15 to $22 \mathrm{~km}$ thick crust.

(iv) The majority of the granitoids constituting the peninsular gneiss terrain were developed in a crust 20 to $35 \mathrm{~km}$ thick and this major event has generally obliterated evidences of the precursor gneisses.

(v) The Closepet granites were emplaced in a crust about $30-35 \mathrm{~km}$ thick.

\section{Influence of crustal thickness on the geotectonic evolution of the terrain}

It has been shown by Bridgwater and Windley (1973), and Windley (1973) that the nature of magmatic activity and the trend of magmatic differentiation are strongly influenced by the thickness of the contemporary crust. A thin crust promotes the rise of magma to higher levels allowing only limited and relatively rapid differentiation into stratiform complexes. Evidences for this are noticed in the Holenarasipur and Nuggihalli greenstone belts (Naqui 1976; Lakshmipathi 1978; Vasudev and Stinivasan 1979). Such stratiform complexes are not noticed in the Kolar and Chitradurga greenstone belts, implying that these younger greenstone belts developed on a comparatively thickened crust. Whereas the platform-mobile zone distinction is characteristic of the younger greenstone belts (Srinivasan and Sreenivas 1972, 1975), such a distinction is not evident in the older greenstone belts of Holenarasipur and Nuggihalli. The latter appear to have evolved in a permobile regime (Naqui 1976).

The similarity of the geosynclinal volcanic rocks and the continental margin volcanics is well-known, and plate tectonic models of geosynclines have been proposed (Dickinson 1971). It has been shown by Sreenivas and Srinivasan (1974) and Ananta Iyer and Vasudev (1979), that the volcanic rocks of the younger greenstone belts have continental margin affinity; the amphibolites of the Kolar greenstone belt have MBB characteristics, and the Chitradurga greenstones island arc volcanic characteristics. These observations show that the platform-mobile 
zone distinction appeared on the crust in this part of the Precambrian shield, when the crust had thickened to more than $15 \mathrm{~km}$, and that a permobile tectonic regime on a thin crust prevailed earlier. It has been shown by Fyfe (1976) that kyanites found along the western margin of the Chitradurga belt (around Ghatitihosahalli) have andalusite cores indicating that the kyanites are secondary after andalusite. This evidence, therefore, supports the view that an early low pressure metamorphism characterizes this Archaean terrain as elsewhere in the world. Such low pressure metamorphism is a reflection of steep geothermal gradients in a thin crust.

The thickness of the South Indian crust has been estimated to be about $36 \mathrm{~km}$ thick by deep seismic sounding (Kaila et al 1979). The geothermal gradient is found to indicate a temperature of $400^{\circ} \mathrm{C}$ at the crust-upper mantle interface (Gupta et al 1979). This would account for a rise of temperature of about $11^{\circ} \mathrm{C} / \mathrm{km}$. It has been estimated that the high-grade mineral assemblages:-noticed in the early greenstone belts are characteristic of a temperature of $650^{\circ} \mathrm{C}$. If the corresponding crustal thickness was about $15 \mathrm{~km}$, it could be deduced that around 3300 m.y. ago, the geothermal gradient was about four times steeper in South India.

The thickness of the crust $2000 \mathrm{~m}$.y. ago when the Closepet granites were emplaced (Venkatasubramanian et al 1971) being in the range of $35 \mathrm{~km}$, and the estimated crustal thickness prior to 3300 m.y. ago being in the range of $7 \mathrm{~km}$ would suggest a crustal thickening rate of about $1 \mathrm{~km}$ every $70 \mathrm{~m} . \mathrm{y}$. in the Archaean-Early Pruterozoic time as evidenced from the geochemical data of the South Indian shield. It is also evident that almost the present thickness of the crust had developed 2000 m.y. ago.

\section{Acknowledgement}

This work forms a part of the INSA Project on "Archaean Geochemistry of the South Indian Shield". The authors thank INSA for their financial support.

\section{References}

Ananta Iyer G V and Narayanan Kutty T R 1978 in Archaean geochemistry (ed.) B F Windley and S M Naqui (Amsterdam : Elsevier) 269

Ananta Iyer G V and Vasudev V N 1979 J. Geol. Soc. India 20419

Beckinsale R D, Drury S A and Holt R W 1980 Nature 283469

Beswick A E and Soucie G 1978 Precambrian Res. 6235

Bhasker Rao Y J and Naqvi S M 1978 in Archaean geochemistry (ed.) BF Windley and S M Naqvi (Amsterđam : Elsevier) 325

Bridgwater D and Windley B F 1973 Geol. Soc. South Africa Suppl. Publ. 842981

Condie K C 1973 Geol. Soc. Am. Bull. 8271

Condie K C 1976 Plate tectonics and crustal evolution (USA : Pergamon) 152

Dickinson W R 1971 Earth Planet Sci. Lett. 10165

Divakara Rao V, Naqui S M, Satyanarayana K and Hussain S 1974 J. Geol. Soc. India 15270

Fyfe W S 1976 Philos. Trans. R. Soc. Lond'. A280 655

Geochemistry group NGRI 1977 Geophys. Res. Bull, 151

Gupta M L, Singh S B, Sharma S R, Saksena B K and Drolia R K 1979 Geophys. Res. Bufl. 17243 
Janardhan A S, Stikantappa C and Ramachandra H M 1978 fin Archaeantgeochemistry (ed.) B F Windley and S M Neqvi (Amsterdam: Elsevier) 127

Jayaram S 1980 Geochemistry and geochronology of certain characteristic rock types of Dharwar cration Ph.D. Thesis Indian Institute of Science 210

Kaila K I, Roy Chowdhury K, Reddy P R, Krishna V G, Hari Narain, Subbotin S I, Sollogub V B, Chekunovi A V, Kharetchko G E, Lazarenko"M A and Ilehenko T V 1979! J. Geol. Soc. India 20307

Lakshmipathi_N S 1978 Chemical petrology and petrogenesis of metamorphic rocks of Holentarasipur. Schist belt, Karnataka State India Unpublished Ph.D. Thesis Indian Institute of Science 250 th

Naqui S M 1976 in The early history of the earth Ed. B F Windley (London: John Wiley) 289 is Naqui S M and Hussain S M, 1979 Can. J. Earth Sci. 161254

Naqvi S M, Viswanatran S and Viswanatha M N 1978 in Archaean geochemistry (ed.) B F Windley and S M Naqui (Amsterdam: Elsevier) 109

Radhakrishna B P and Vasudev V N 1979 J. Geol. Soc. India 18j525

Saha A K 1978 J. Geol. Soc: India 20375

Sreenivas B L and Srinivasan:R.1974 J. Geol. Soc. India 1375

Sreenivas B L and SrinivasanR $1974 \quad J$. Geol. Soc. India 15390

Srinivasan R and Sreenivas B L 1972 J. Geol. Soc. India 1384

Srinivasan R and Sreenivas B L 1975 Geol. Surv. India Misc. Publ. 2349

Swaminath J, Ramakrishnan M and Viswanatha M N 1976 J. Geol. Soc. India 20170

Swaminatn J, Ramakrishnan M and Viswanatha M N 1976 Rec. Geol. Surv. India 107 (2) 149

Vasudev V N and Srinivasan R 1979 J. Geol. Soc. India 20170

Venkatasubramanian V S and Narayanaswamy R 1974 J. Geol. Soc. India 15318

Venkatasubramanian V S, Iyer S S and Pal S 1971 Am. J. Sci. 27043

Windley B F 1973 Geol. Soc. Africa Spl. Publ. 3319 